\title{
A Clinical Investigation of the Performance and Safety of Epaderm $₫$, an Emollient Cream [Corrigendum]
}

\author{
August S, Granier S, Tighe MP, Tbaily LW, Ahlbom \\ H. Clin Cosmet Investig Dermatol. 2021;14:909-920.
}

The authors have advised the author list on page 909 is incorrect. The correct author list and affiliations are as follows.

Suzannah August ${ }^{1}$

Stephen Granier ${ }^{2}$

Mark P Tighe ${ }^{1}$
Lee W Tbaily ${ }^{1}$

Sabrina Chowdhury ${ }^{3}$

Henrik Ahlbom ${ }^{3}$

${ }^{1}$ University Hospitals Dorset NHS Trust, Dorset, BH15 2JB, UK; ${ }^{2}$ Whiteladies Medical Group, Bristol, BS8 2PU, UK; ${ }^{3}$ Mölnlycke $\AA$ Health Care, Gothenburg, 402 52, Sweden

The authors apologize for this error.

\section{Publish your work in this journal}

Clinical, Cosmetic and Investigational Dermatology is an international, peer-reviewed, open access, online journal that focuses on the latest clinical and experimental research in all aspects of skin disease and cosmetic interventions. This journal is indexed on CAS
The manuscript management system is completely online and includes a very quick and fair peer-review system, which is all easy to use. Visit http://www.dovepress.com/testimonials.php to read real quotes from published authors. 